This is an electronic reprint of the original article. This reprint may differ from the original in pagination and typographic detail.

Author(s): Vanhanen, Sari; Heikkilä, Elli

Title: $\quad$ Multi-professional work practices in the field of immigrant integration - examples of collaboration between the police and social work

Year: $\quad 2017$

Version:

Please cite the original version:

Vanhanen, S., \& Heikkilä, E. (2017). Multi-professional work practices in the field of immigrant integration - examples of collaboration between the police and social work. Migration Letters, 14(2), 273-284. https://doi.org/10.33182/ml.v14i2.332

All material supplied via JYX is protected by copyright and other intellectual property rights, and duplication or sale of all or part of any of the repository collections is not permitted, except that material may be duplicated by you for your research use or educational purposes in electronic or print form. You must obtain permission for any other use. Electronic or print copies may not be offered, whether for sale or otherwise to anyone who is not an authorised user. 


\title{
Multi-professional work practices in the field of immigrant integration - examples of collaboration between the police and social work \\ Sari Vanhanen ${ }^{\Upsilon}$ \\ Elli Heikkilä ${ }^{\S}$
}

\begin{abstract}
Development of the professional competences and work practices are required when promoting successful immigrant integration in a constantly diversifying society. One work method applied in this field is multi-professional collaboration. Cooperation between the authorities at the local level reduces the overlap between services and brings together expertise and resources, resulting in not only added value but also more proactive and less costly service. Thus, collaboration can involve actors from various sectors, like NGOs or ethnic minority communities. In this article examples of collaboration in two different multi-ethnic contexts are introduced: first, in school and second, in a suburb. The focus here is especially on the joint work practices of the police and social work besides the other actors in these two surroundings. Despite the differences in their work orientation, mutual aims and practices are found. Collaboration between the police and social work is valued not just in facing problematic situations, but also in emerging environments where the host society and immigrants can exchange their views and expand common strategies for an active interaction and coexistence.
\end{abstract}

Keywords: multi-professional collaboration; the police; social work; immigrant integration.

\section{Introduction}

Migration and the successful integration of immigrants have turned to be one of the main issues in the European Union. This is connected to the fact that immigrants might not be familiar with the service system in the new host society. Various professional work methods, intercultural skills and integration practices have been developed and are constantly looked for to promote two-way integration (British Council, Booz Allen Hamilton \& Ipsos Public Affairs, 2013). Among these work methods, multi-professional cooperation has been used and applied in various combinations and contexts. However, collaboration in this field of work has not been studied to such an extent. This is why it is necessary to analyse what is the added value of multi-professional collaboration in immigrant integration.

\footnotetext{
$\Upsilon$ Sari Vanhanen, University of Jyväskylä, Finland. E-mail: sari.m.vanhanen@gmail.com. $\S$ Elli Heikkilä, Migration Institute of Finland, Turku, Finland. E-mail: elli.heikkila@utu.fi.

Acknowledgement: This study was supported by Migration Institute of Finland.
} 
The main aim of this article is to analyse the multi-professional collaboration between two authorities, the police and social work, with a specific focus on the cooperation in promoting successful immigrant integration at a local level.

Why these two professions are examined more closely? Collaboration between the police and social work is necessary not just in facing problematic situations, but also in evolving environments where the host society and immigrants can exchange their views and expand common strategies for an active interaction and coexistence. These two professions are able to both stimulate participation and active citizenship, and prevent escalation of conflicts at a family or community level (McLaughlin, Reubsaet \& Vanhanen, 2011: 8). Their duty is to support citizens in challenging life situations. Furthermore, their work with people is taking place at the street-level as public service workers who interact directly with citizens in the course of their work (Lipsky, 1980; see also Hagelund, 2009; Nordberg \& Wrede, 2015). Some immigrants might have negative attitudes towards the authorities because of earlier experiences in their origin countries. Especially, the police can be regarded with mistrust and even fear. This is very much connected to trust on the society level (Egharevba, 2009; Björkgren Cuadra \& Fransson, 2012).

This article is based on a European Commission funded research and development project, "Immigrants, Police and Social work" (acronym IPS, 2009-2011) implemented in Finland, the Netherlands, Sweden, Spain and the United Kingdom. The IPS-project's qualitative data were gathered from each partner country and consisted of 25 examples of good or promising collaborative practices between the police, social work and immigrants (see Heikkilä et al., 2011). The research material, chosen five examples in each partner country, included the interviews of police officers, social workers and other key-actors, as well as written documents. The interviews were semi-structured and conducted by researchers in each country. The used documents were background information connected to chosen examples, national wide policy reports and programmes as well as research. Besides the collection of good practices, also a joint professional training course for the police and social workers was implemented in four partner countries. An active dialogue with the participants enriched the findings of the project (Halttunen et al., 2011).

In this article, two examples of collaboration from the IPS-project are chosen from the multi-ethnic contexts: first, in a school environment in the Netherlands and the second, at the community level in a suburb in Sweden. In both examples, the cooperation involves also other actors besides the police and social work. Similar kind of collaboration was found in other project partner countries, e.g. concerning the work with the youth in school environment or community mediation.

Before introducing two local cases of multi-professional collaboration in immigrant integration, the theoretical approach is represented. Afterwards, the outcomes are analysed by examining the gained experiences of the cooperation faced by the actors involved. Finally, the conclusions are drawn including aspects for further development of cooperation in a wider perspective. 


\section{Theoretical approach}

When analysing multi-professional collaboration connected to immigrant integration, it is relevant to ask what the requirements for multi-professional cooperation in this specific context are. Increasing immigration results in, as such, new competence-based requests for various public service professions and the third sector, NGOs. Yet, it is necessary to analyse how cooperation promotes twoway integration proactively: what kind of expertise - or whose knowledge - is valued in creating, implementing and evaluating cooperation at the local level?

According to the common basic principles for immigrant integration policy in the European Union, integration is seen as a dynamic, two-way process between the newcomers and the receiving society aiming at the mutual accommodation. However, the idea of integration is more complex. Rather than asking how immigrants can be integrated, we should ask how they can become equal citizens and be bound to the rest of the society by the ties of common belonging. This can be seen as a two-way process requiring a broad consensus on what is expected of each party (Parekh, 2008: 85-87). Furthermore, at the national level the process of integration is closely connected to the multicultural policies which can be viewed in two reciprocal ways: both as a form of claims-making by minority groups, and as a way in which the dominant society and its political system accommodate and manage diversity (Kivisto \& Wahlbeck, 2013; Borevi, 2014; Kivisto, 2015). Promoting two-way integration can be characterised as proactive work where the ideas of inclusion and emancipation are underlined. Proactive work includes an opportunity for mutual interaction, which means an initiative way of working in advance e.g. counselling and guidance, or sharing relevant information. The focus may involve individuals, families or communities (see e.g. Forkby \& Johansson, 2016).

Multi-professional working can be called in various terms like inter-professional working, multi-agency working or partnership working. It contains a shared understanding that "a joined up" approach with "joined up thinking" would reduce the overlap between services and promote the pooling together of expertise and resources, resulting in not only added value but a more effective and less costly service (McLaughlin, Reubsaet \& Vanhanen, 2011: 20; see also Isoherranen, 2012; Rolandsson, 2015; Vanhanen, 2016).

The value of undertaking a multi-professional approach is in being able to respond holistically to needs and being able to arrive at a more developed understanding of the problem and its potential solutions (Morris, 2008). It is envisaged that such work would develop a reciprocity whereby the multi-professional relationship is seen to be of mutual benefit to each of the partners helping them to achieve their goals whilst reducing risk and resources (Glasby \& Dickinson, 2008). Multiprofessional working can range from the two individuals or groups sharing information, consulting with each other, coordinating activities, being subject to a 
joint management, forming a partnership organisation or a formal merger (Glasby, 2007).

The requirements for effective collaboration have been identified e.g. in health and social services. First of all, the actors need to be aware of the role of other professionals as well as having a clear understanding of their own role. Alongside with the need for open and honest communication, a motivation and commitment to collaborative practice are required. Without time and opportunity to develop trust and mutual respect collaboration is in risk of collapsing: here, a management support is a prerequisite for an effective interpersonal practice. This requires also an opportunity to develop a model of shared power with clear responsibilities. However, the main necessity is to define a joint aim for collaboration. Otherwise the structure becomes more important than the subject itself (Quinney, 2006).

An analysis of the immigrant work carried out by the police in Turku, Finland (Heikkilä, Pikkarainen \& Wilkman, 2008) showed that the police are often contacted due to matters that actually belong to the duties of social welfare authorities. With regard to interest group activities, the mutual exchange and flow of information were found to be important. The police officers interviewed in the study believed that better knowledge of social work could help the police in further advising their clients in order to secure the receipt of further assistance, also in situations which do not actually fall within the sphere of police duties.

It is worth to emphasise that in the field of immigrant integration, not only a professional expertise but also experience-based expertise is relevant e.g. by certain spokespersons of ethnic communities or organisations (Lippert \& Pyykkönen, 2012; Heikkilä et al., 2011; McLaughlin, Reubsaet \& Vanhanen, 2011). This is essential in two-way integration process. In some cases like in school welfare services, this collaboration might already have a certain structure with an operating model, and "the issue of immigrant integration" is added to the agenda (see e.g. Säävälä, 2012). Particularly important is to keep in mind that the cooperation should not be ruled just by the authorities but instead it must be based on the needs of the people they are working with (Halttunen et al., 2011: 11; Forkby \& Johansson, 2016).

\section{Two examples of multi-professional cooperation}

In this article, two chosen examples of multi-professional cooperation represent work in different multi-ethnic surroundings: one in a school environment and another in a suburb. A school is a vital sphere of everyday life for youngsters. In a suburb, the main principle in community work is to engage and mobilise inhabitants and listen to their own initiatives and needs. Both examples describe the possibilities and problems in promoting two-way integration at a local level. Further on, the role of proactive work is relevant in these examples.

More closely, the first example describes the actions of the School Safety Team in the Netherlands (Berends, Danker \& Reubsaet, 2011). Cooperation includes actors 
from the schools, including school social workers, together with the municipality and the police. The teams are a response to alarming truancy figures and reported incidents on preparatory secondary vocational education schools in Amsterdam. Secondary schools have become large scale institutions, combined with a mixture of cultures, including also children from less privileged families which might have a lack of understanding in official language. This can cause communication problems between the school and the families. Due to an increase of unrest and crime, safety in and around school has been a primary concern for some decades resulting in many initiatives to strengthen safety in schools.

The second example covers community work in one of the suburban areas in the city of Gothenburg, Sweden. This part of the city, Hjällbo, has been described as one of the most segregated areas in Sweden. Over 90 percent of inhabitants were born outside of Sweden or had at least one parent who was born abroad. Because of the high unemployment rate in the area, many people have contacts with social workers in order to get economic assistance. Also the costs for social treatment of children and youth at external institutions have been remarkably high (Carle et al., 2011). This is why there was an interest to mobilise different professionals locally and collect their experiences and knowledge in order to meet the needs of children, the youth and their families in a more effective way.

\section{School Safety Teams in the Netherlands}

The aim of the School Safety Teams in the Netherland has been to support the schools and their surroundings to add the safety for children to go and stay in school (Berends, Danker \& Reubsaet, 2011). Schools are selected by a relatively high number of incidents recorded at the police stations and truancy offices. In a close cooperation with the school personnel, the team observes, advices and supports pupils at school with the aim to improve the safety and truancy policies in school. It tries to have a directive influence, through supporting the expertise of professionals. The team's action is a temporary intervention for a one year period.

School Safety Teams started in 2009 on four locations in Amsterdam. A high percentage of police officers in the corps are immigrants themselves, mainly from Turkish, Moroccan and Surinamese origin. The schools where the teams work often have an 80 to 90 percent immigrant population. Sometimes culture plays a role when the school has to contact with the parents concerning sensitive issues like a sexual offence. This type of topic can be a taboo for a family. The target group is not, however, specifically the immigrants, but socially vulnerable children.

A core task of school is to provide good pedagogical, social and physical climate for pupils at school. Each school has a Care and Advice Team, which pays a specific attention to pupils who need extra support. All in all, there are professionals focusing on learning or behavioural problems, school social workers focusing on the background and home situation of the pupil and care coordinators who work 
with reports of a mentor and coordinate external help. Truancy has to be reported at the regional registration and coordination centre.

The School Safety Team works with the schools and supports professionals like teachers, mentors, concierges, care and safety coordinators. The team consists of a police officer in school, one or two assistant attendance officers working closely with the attendee bureau, and a project coordinator provided by school. This can for example be a teacher or a janitor. The team does not want to establish itself but rather strengthen existing care, safety and prevention structures in school.

The police officer participates actively in school on a daily basis in a uniform together with the attendee assistant. When the pupils arrive (s)he is present and if necessary (s)he has a talk with pupils about their behaviour. All types of unexpected behaviour are addressed. The police officer works according to the core tasks of the police: caring, service, taking action, regulating, tracing and prosecuting. The attendee assistant has also wide range of tasks: (s)he monitors and controls, does activities like a head count in class, registers pupils that are late, visits homes, sometimes even collects pupils at home with the attendee assistant bus. The attendee assistant focuses on truancy and the police on safety. In practice, truancy can be related to police matters and vice versa, e.g. a girl stays away from school (truancy case) since she was sexually assaulted (police matter), or pupils who play truant are involved in criminal activities outside of school.

The School Safety Team's cooperation with school mentors and school social work is significant. They are the primary agents for addressing pupils when there are alarming signs in their behaviour. The police officer and the attendee officer are highly dependent on these first lines of communication. An important role has the project coordinator who connects and translates information about effective elements and obstacles to the school management. (S)he also brings back information and suggestions for solutions from the management to the team.

\section{Outcomes}

When looking at the School Safety Teams (Berends, Danker \& Reubsaet, 2011) and the gains in their activities, solutions that have been presented are: a new long term safety plan, a special class for truants and a bullying prevention protocol. The teams set out to be practical intervention by making visible the context of problems and filtering out tools to make schools more effective in handling incidents and cross normative behaviour. Costs of the action are low since school, the police and the municipality provide personnel out of the regular staff.

The School Safety Teams' results show a clear diminishing of truancy, early recognition of pupils at risk, more pupils on time in schools and a better contact with parents. Schools provide the possibility to reach youth at risk before they leave the school. In school there is a chance to confront them instantly with an improper behaviour. There is thus a chance that these pupils see the consequences 
of their behaviour and are more likely to make more constructive choices in the future.

One element in making the actions successful is a productive cooperation with schools. Sometimes this requires an effort to come to a mutual agreement. It is essential that the motive for installing the teams is clear and temporary, and used in schools with a high amount of truancy and improper behaviour. It intends to make schools safer and more successful in their primary target to educate and upbring pupils. Sometimes the pupils find it hard to report incidents; they still have to deal with their group mates and feel unsafe if they point someone out who harmed them. The School Safety Team wants, however, to stimulate and strengthen the social skills of pupils and their feeling of safety at school.

Another element for success is that involved partners communicate well and work transparently, so that the adequate information is accessible and a crisis can be prevented rather than cured. Schools participate voluntarily, but are not always comfortable with a School Safety Team in their building. Some school directors are afraid that the presence of a police officer in the school affects negatively to the image of the school. This is a challenge since sometimes a school balances between different issues: on the one hand they want to have a good image as a safe school, and on the other hand they inform all incidents to become safer.

The team intends to be a temporary means to an end and to give back the full responsibility to the school, pupils and parents after one year. For schools the findings are not necessarily new, but the team helps to look at them in a different light, and stimulate a broader vision of school safety.

\section{Community work in a suburb of Gothenburg, Sweden}

Community work in the suburb of Lärjedalen in Gothenburg including Hjällbo is targeted to a whole community with a goal to engage and mobilise parents and listen to their own initiatives and needs. It aims to create a better future for the most vulnerable children and young people in the area (Carle et al., 2011).

In all suburbs in Gothenburg, there is a collaboration unit between the authorities called SSPF (social tjänst, skola, polis och fritid). In this unit, there are representatives from professionals working at social services, school, the police and youth centres. Development of the collaboration between the police and social work in community work started in 2010. The vision was to employ police officers and social workers who should work on prevention in the area. The reason why the police got involved in the community work was to decrease the criminality rate and to make the community a safer place to live in (Carle et al., 2011).

The methods used in community work are diverse. One method is to reach out the whole community through so called Worry meetings. At these meetings, the multiprofessional collaboration unit informs the inhabitants about what is going on and how or why the authorities may be worried about children and youngsters in the area. The attendants at those meetings are parents who live in the area, as well as 
representatives from different organisations and authorities that are active locally. Another method is to listen to the community members and their current needs and wishes. Based on the issues coming up, the community workers plan new meetings with a specific theme. These theme and dialogue meetings are held once a month.

The third method is to support community members' own initiatives to organise themselves. One example is a network of fathers with a Somali background who meet regularly. Another example is a group of parents who have started an association called Active Parents. Social workers and the police have a supportive role in both groups. The fourth method is to work as mediators between the authorities and different community members when there has been a specific incident between a family and the police or social services. The purpose is to explain to one or several community members about the working methods and why the police or social services are acting in a certain way. The main aim is to build up more trustful relations between the community members and local authorities. The fifth method is to inform the authorities about how the community members have experienced the work methods and interaction with the authorities. This information is valuable in order to improve various work methods of the authorities in their daily work (Carle et al., 2011).

\section{Outcomes}

One of the outcomes of the collaborative community work between social workers and the police (Carle et al., 2011) has led to the mobilisation of parents who want to work for a safer place to live in and for a better future for their children. The main aim is to promote people in the local area to act and take control over their own life situation as well as to strengthen social inclusion of children and the youth.

Community policing represents a method of managing the basic task of the police with quality and efficiency, in a citizen-oriented manner. Its objective is to provide security and a sense of safety, and to reduce and prevent crime and public disturbances. In so doing this maintains the social order and upholds a positive image of the police which encourage trust between communities and the police as well with the other authorities.

It was noticed that an important facilitating factor in community work is the involvement of social workers with the same ethnic background as the target group. The methods used in the community work can be seen as the tools for social mobilisation and empowerment on a group level and on a community level. People in the local area are encouraged to act and take control over their life situation. The authorities involved - social workers and police officers - are also working as bridge builders and mediators when there are misunderstandings in the relations between the community members and the authorities. 
In general, authorities in the host society should develop methods of engagement to ensure the immigrant voices can be heard and involved in contributing to community work.

\section{Conclusions}

The police and social workers are essential local authorities who meet immigrants in their work. A lot of work is still being done separately, though the spheres of operation between authorities converge in a multicultural community. As the society changes, e.g. because of migration, the requirements for professional competences, including skills, knowledge and attitudes, also mutate constantly. These wider dynamics create a need for a greater understanding and sensitivity to norms and values prevalent in cultures other than one's own. A person who is interculturally competent is able to communicate effectively and empathetically with individuals and groups from diverse cultures (McLaughlin, Reubsaet \& Vanhanen, 2011: 8).

According to the findings, the collaboration between the police, social work and other actors involved is a valuable asset in the empowerment of the communities, as described in the example from the suburb in Gothenburg. Cooperation is mostly built for an information exchange where all actors are both mediators and receivers. In partnership with the other actors, the police are responsible for maintaining order and security in the community and in the schools, as the experiences show. The police, and also social workers, can serve as "detectors" of problems due to their daily contact with many parts of the population (see Feltes, 2006: 129), but also can be very useful as facilitators and promoters of good relations in the society.

Cooperation between the police and social work in the immigrant integration is a central preventive action, e.g. when by paying attention to unexpected behaviour and truancy (the example of school) or promoting social mobilisation and empowerment on a community level (the example of the suburb).

Among the authorities, there are some immigrant background policemen and social workers, who have cultural knowledge for benefiting in the integration work. Also in the immigrant communities, there are contact persons, who operate as socalled cultural interpreters as they are aware of what young people are doing and know how to reduce the causes of crime and prevent the criminal behaviour of the immigrant youth (see Heikkilä, Pikkarainen \& Wilkman, 2008: 132). They have an important role also in creating trust towards authorities among immigrants. Individuals may have very different experiences for example of the police in their country of origin, and this may affect the initial perception of the police in the host country (see Egharevba, 2009: 17-18). It is highlighted that with more recruits, for example, to the police force from immigrant backgrounds, trust in the police can be further increased among different population groups (Singh, 2008). 
Cooperation between the police and social work may promote immigrant integration and make the work of these professionals more rewarding. Yet, it should be noted that this is not a risk-free activity. If the process is poorly carried out it may damage the relationships between the police and social workers and may even make matters worse for the immigrants. In practice, resources are often scarce, or the ability of an individual practitioner to build up wider networks and develop new methods in multi-professional cooperation is inadequate. The organisations have to focus on their key tasks in the case of limited personnel, time and financial resources. Furthermore, the confidential information stored by different organisations can prevent mutual collaboration (Lumio et al., 2012; Heikkilä, Gómez Ciriano \& Ojalehto, 2011).

In a wider perspective, there is a need to develop multi-professional work practices further on and to offer more regular opportunities for a joint discussion "around the same table". Collaboration might already exist but it is sometimes strongly personalised, i.e. depending on the active role of one or two key-professionals with his/her networks. For both creating and maintaining cooperation the supportive involvement of management is crucial (Halttunen et al., 2011; Heikkilä et al., 2011).

When looking at the two-way integration in practice, there are good examples of consultation with immigrants in an advisory role, but there is still plenty of work to do in making this more collaborative and the inclusion of immigrants a standard rather than an exception. Every action in improving the engagement of immigrants and the authorities to exchange perspectives, to identify challenges and develop solutions together can strengthen the inclusion.

\section{References}

Berends, J., Danker, M. \& Reubsaet, H. (2011). The Dutch Approach; Working Together for Liveable Communities. In: E. Heikkilä, M. Danker, E. Gómez Ciriano, H. McLaughlin \& H. Reubsaet (eds.) Working Together for Better Integration - Immigrants, Police and Social Work. Institute of Migration, Migration Studies C 18. Turku.

Björkgren Cuadra, C. \& Fransson, O. (2012). Tillit och förtroende. Ständiga utmaningar för professioner. [Trust and confidence. Constant challenges for professionals]. Gleerups Utbildning $A B$.

Borevi, K. (2014). Multiculturalism and Welfare state Integration: Swedish Model Path Dependency. Identities: Global Studies in Culture and Power, 21 (6): 708-723.

British Council, Booz Allen Hamilton \& Ipsos Public Affairs (2013). Culture at work. The value of intercultural skills in the workplace. British Council. https://www.britishcouncil.org/ sites/default/files/culture-at-work-report-v2.pdf - Accessed in 9.3.2016.

Carle, J., Wikström, H., Melander,. C \& Backenfall, P. (2011). Practices for Generating Integration and Inclusion. In: E. Heikkilä, M. Danker, E. Gómez Ciriano, H. McLaughlin \& H. Reubsaet (eds.) Working Together for Better Integration - Immigrants, Police and Social Work. Institute of Migration, Migration Studies C 18. Turku.

Egharevba, S. (2009). Immigrant's relations with the police in Finland: A Lamarckism or a self-induced exercise. Institute of Migration, Siirtolaisuus-Migration 2009 (2): 13-24. 
Feltes, T. (2006). Immigration, Integration and Insecurity - the Role of Police Ethics and Police Training. In: J. Fehérváry, G. Hanak, V. Hofinger \& G. Stummvoll (eds.) Theory and Practice of Police Research in Europe. European Police College, CEPOL Series No. 1. Vienna.

Forkby, T. \& Johansson, A. (2016). Konsten att hänga i luften så länge som möjligt. Om mobiliserande trygghetsarbete kring ungdom och social oro i Angered. [The art of hanging around. About mobile security work amongst the youth and social unrest in Angered] The University of Gothenburg. http://www.gu.se/forskning/publikation/? publicationld=234743 - Accessed in 2.11.2016.

Glasby, J. (2007). Understanding Health and Social Care. Bristol, Policy Press.

Glasby, J. \& Dickinson, H. (2008). Partnership Working in Health and Social Care. Bristol, Policy Press in association with Community Care.

Hagelund, A. (2009). Dealing with the Dilemmas: Integration at the Street-level in Norway. International Migration, 48 (2): 79-102.

Halttunen, T., Lundqvist, K., Ojalehto, M., Tuominen, H. \& Vanhanen, S. (2011). Working Together for Better Integration. A joint Professional Course on Intercultural Competences and Cooperation for Police and Social work. A manual. http://www.ipsproject.fi/ips12072011.pdf - Accessed in 3.2.2016.

Heikkilä, E., Pikkarainen, M. \& Wilkman, S. (2008). Poliisi ja maahanmuuttajat Turussa tänään. [Police and immigrants today in Turku]. In: A. Tanner (ed.) Poliisi ja maahanmuuttajat - Kohti kotoutumista edistävää vuorovaikutusta [Police and immigrants - Towards cooperation in promoting integration]. Poliisiammattikorkeakoulun raportteja 67/2008.

Heikkilä, E., Danker, M., Cómez Ciriano, E., McLaughlin, H. \& Reubsaet, H. (eds.) (2011). Working Together for Better Integration - Immigrants, Police and Social Work. Institute of Migration, Migration Studies C 18. Turku. http://www.migrationinstitute.fi/ files/painetutc-sarja-englanninkielinen/workingtogetherforbetterintegration.pdf Accessed in 19.10.2016.

Heikkilä, E., Cómez Ciriano, E \& Ojalehto, M. (2011). Reflections. In: E. Heikkilä, M. Danker, E. Gómez Ciriano, H. McLaughlin \& H. Reubsaet (eds.) Working Together for Better Integration - Immigrants, Police and Social Work. Institute of Migration, Migration Studies C 18. Turku.

Isoherranen, K. (2012). Uhka vai mahdollisuus - moniammatillista yhteistyötä kehittämässä. [Threat or opportunity. Promoting interprofessional collaboration.] Helsingin yliopisto, Sosiaalitieteiden laitoksen julkaisuja 2012:18.

Kivisto, P. (2015). Pluralism and the dynamics of contemporary integration. In: E. Heikkilä, A. Kostiainen, J. Leinonen \& I. Söderling (eds.) Participation, Integration, and Recognition: Changing Pathways to Immigrant Incorporation. Institute of Migration, Migration Studies C 24/ Histories 4. Turku.

Kivisto, P. \& Wahlbeck. Ö. (eds.) (2013). Debating Multiculturalism in the Nordic Welfare States. Palgrave Politics of Identity and Citizenship Series. Palgrave Macmillan.

Lippert, R., \& Pyykkönen, M. (2012). Introduction - Immigration, governmentality, and integration assemblages. Nordic Journal of Migration Research, 2 (1): 1-4.

Lipsky, M. (1980). Street-Level Bureaucracy. Dilemmas of the Individual in Public Services. Russell Sage Foundation, New York.

Lumio, M., Susi, R., Heikkilä, E. \& Kuoppamäki, S.M. (2012). Muuttuvan viranomaisyhteistyön moninaiset haasteet. Kolme tapaustutkimusta maahanmuuttajien kotouttamisesta ja lapsiin kohdistuvien väkivalta- ja hyväksikäyttötapausten selvittämisestä. [Many-sided challenges of changing authority cooperation. Three case studies of integration of 
284 Multi-professional work practices in the field of immigrant integration

immigrants and clarification of violence and exploitation cases of children]. Siirtolaisuusinstituutti, Web Reports 73. Turku.

McLauglin, H., Reubsaet, H. \& Vanhanen, S. (2011). Introduction. In: E. Heikkilä, M. Danker, E. Gómez Ciriano, H. McLaughlin \& H. Reubsaet (eds.) Working Together for Better Integration - Immigrants, Police and Social Work. Institute of Migration, Migration Studies C 18. Turku.

Morris, K. (2008). Conclusions. In: Morris, K. (ed.) Social Work and Multi-Agency Working: Making a Difference. Bristol, Policy Press.

Nordberg, C. \& Wrede, S. (2015). Street-Level Engagements: Migrated Families Encountering the Local Welfare State. Nordic Journal of Migration Research, 5 (2): 54-57.

Parekh, B. (2008). New Politics of Identity. Political Principles for an Interdependent World. Palgrave Macmillan.

Quinney, A. (2006). Collaborative Social Work Practice. Exeter: Learning Matters.

Rolandsson, B. (2015). Partnerships with the police - logics and strategies of justification. Qualitative Research in Organizations and Management: An International Journal, 10 (1), 2-20.

Singh, T. (2008). Maahanmuuttajapoliisit ovat tarpeen. [Immigrant-background police is needed]. Helsingin Sanomat, 12.11.2008.

Säävälä, M. (2012). The Burden of Difference? School Welfare Personnel's and Parents' Views of Wellbeing of Migrant Children in Finland. Finnish Yearbook of Population Research, 47: 31-50.

Vanhanen, S. (2016). Emerging Expertise? Multiagency Collaboration Described in Local Integration Programmes in Finland. Finnish Yearbook of Population Research, 50: 85-96. http://ojs.tsv.fi/index.php/fyp/article/view/49665 - Accessed in 19.10.2016. 